\title{
MAKNA KESEJAHTERAAN DALAM SUDUT PANDANG EKONOMI ISLAM
}

\author{
Didi Suardi \\ Program Studi Ekonomi Syariah \\ Sekolah Tinggi Ekonomi Syariah Islamic Village Tangerang, Banten \\ Email: didi@stes.isvill.ac.id
}

\begin{abstract}
The meaning of Welfare in Islamic economics aims to achieve overall human welfare, namely material welfare, spiritual and moral well-being. The concept of sharia economic welfare is not only based on the manifestation of economic values, but also spiritual and moral values. The conception of welfare and happiness (falah) refers to the objectives of Islamic law by maintaining the 5 principles in the maqashid syari'ah, namely the attack of religion (ad-ddin), the attack of the soul (an-nafs), the attack of reason (al-aql), the attack of the offspring ( annasl) and access to property (al-mal). In detail, the objectives of Islamic economics can be explained as follows: 1). Economic welfare includes the welfare of individuals, communities and the state, 2). The fulfillment of basic human needs, including eating, drinking, clothing, shelter, health, education, security and a state system that ensures the fulfillment of basic needs fairly, 3). Power usage optimally, efficiently, effectively, economically and not wasted, 4). Distribution of assets, wealth, income and development results fairly and equitably, 5). Guarantee individual freedom, 6). Equal rights and opportunities, and 7). Cooperation and justice.
\end{abstract}

Keywords: Strategy, Islamic Economics, Welfare of the People

\begin{abstract}
Abstrak
Makna Kesejahteraan dalam ekonomi syariah bertujuan mencapai kesejahteraan manusia secara menyeluruh, yaitu kesejahteraan material, kesejahteraan spiritual dan moral. Konsep kesejahteraan ekonomi syariah bukan saja berdasarkan manifestasi nilai ekonomi, tetapi juga nilai spiritual dan moral. Konsepsi kesejahteraan dan kebahagiaan (falah) mengacu pada tujuan syariat Islam dengan terjaganya 5 prinsip dalam maqashid syari'ah, yakni terjanganya agama (ad-ddin), terjanganya jiwa (an-nafs), terjanganya akal (al-aql), terjanganya keturunan (an-nasl) dan terjanganya harta (al-mal). Secara terperinci, tujuan ekonomi Islam dapat dijelaskan sebagai berikut: 1). Kesejahteraan ekonomi mencakup kesejahteraan individu, masyarakat dan negara, 2). Tercukupinya kebutuhan dasar manusia, meliputi makan, minum, pakaian, tempat tinggal, kesehatan, pendidikan, keamanan dan sistem negara yang menjamin terlaksananya kecukupan kebutuhan dasar secara adil, 3). Penggunaan berdaya secara optimal, efisien, efektif, hemat dan tidak mubazir, 4). Distribusi harta, kekayaan, pendapatan dan hasil pembangunan secara adil dan merata, 5). Menjamin kebebasan individu, 6). Kesamaan hak dan peluang, dan 7). Kerjasamaan dan keadilan.
\end{abstract}

Kata Kunci: $\quad$ Strategi, Ekonomi Islam, Kesejahteraan Umat 


\section{Dasar Pemikiran}

Ekonomi merupakan bagian yang tidak bisa terpisahkan dari kehidupan manusia dalam mengaktualisasikan dirinya untuk mencapai tujuan hidupnya. Islam sejalan dengan fitrah manusia yang bersifat holistik (syumul). Sejalan dengan perkembangan zaman dengan banyaknya kebutuhan manusia yang harus terpenuhi, maka dibutukan pula sebuah sistem ekonomi yang dapat mensejahterakan semua lapisan masyarakat (Nasution, 2007). dimana muncul suatu pandangan yang menempatkan aspek material yang bebas dari dimensi moral. Pandangan ekonomi materialisme ini yang kemudian mendorong perilaku manusia menjadi pelaku ekonomi yang hedonistik, sekularistik dan materialistik.

Berlangsungnya ekonomi pembangunan dunia ditandai dengan adanya kemajuan sains dan teknologi yang penuh dengan kompetisi (Aedy, 2011). Sistem ini menjadi semakin popoler dan mendewakan kebebasan sebagai tulang punggung pembangunan ekonomi. Namun, dalam perjalanannya sistem kapitalisme ini gagal menciptakan pemerataan dan keadilam pembangunan, sehingga menyisahkan jarak ketimpangan yang semakin luas antar individu, kelompok dan wilayah dalam sector perekonomian, bahkan antar negara khusunya negara maju dan negara sedang berkembang.

Indonesia sebagai negara berpenduduk muslim terbesar di dunia masih kerap dikaitkan dengan persoalan kemiskinan dan pengangguran. Di tingkat internasional, Indonesia berada di peringkat yang jauh lebih rendah dibanding negara tetangga. Menurut Sutrisno Iwantono menyatakan bahwa kondisi perekonomian Indonesia secara makro masih menunjukkan performa yang baik, namun di sisi lain ketimpangan dan kemiskinan masih menyelimuti sebagian besar rakyat Indonesia (Nailufarh, 2010). Permasalahan ekonomi yang dihadapi oleh bangsa Indonesia saat ini dinilai semakin menjauh dari tingkat kesejahteraan, hal ini bisa dilihat dari faktor pemicu terjadinya kesenjangan, ketimpangan dan pengangguran di masyarakat. Oleh karena itu, perlu adanya pemecahan masalah dan kerjasama semua pihak, baik dari peran masyarakat maupun dari kebijakan pemerintah untuk mendorong perekonomian masyarakat.

Secara khusus, masalah pokok ekonomi rakyat seperti kemiskinan dan pengangguran kemungkinan besar akan tetap bertahan, karena masih banyaknya 
kepentingan birokrasi dan intervensi penguasa dan/atau kolomerat. Situasi ini akan terus memburuk, jika pemerintah terus memaksakan agenda-agenda ekonomi neo-liberal yang mengsampingkan kepentingan rakyat. Di luar intervensi modal internasional, ekonomi Indonesia pun sudah terlanjur terperangkap pada masalah-masalah struktural yang cukup berat, seperti aksi korupsi yang sudah menggurita sehingga menguras volume APBN, pembayaran angsuran pokok dan bunga utang luar negeri yang hampir menguras sepertiga APBN, kenaikan harga minyak bumi dunia yang berakibat pada terjadinya pembengkakan subsidi BBM dan derasnya kepentingan arus impor yang menyebabkan semakin terpinggirkannya pelaku ekonomi lokal.

Jika ini terus berlanjut, upaya peningkatan kesejahteraan rakyat mustahil dapat dilakukan, program-program pemerintah yang bersifat karitatif dan parsial, dalam jangka pendek program-program instan ini mungkin menolong. Akan tetapi untuk jangka panjang tidak cukup, perlu adanya estapet program-program permanen yang berjangka, terperogram dan terus berkesinambungan. Belum lagi, tingkat kemiskinan yang relative masih cukup tinggi, hal ini menjadi tantangan pemerintah untuk mengubah kekuatan masyarakat menjadi sumber daya yang produktif terutama dalam memenuhi pasokan kebutuhan dalam Negeri, tidak serta merta hanya tergantung pada produk impor. Hadiranya barang-barang impor yang murah dalam jumlah yang sangat besar, membuat pelaku ekonomi kecil dan menengah di Indonesia semakin sulit bangikit dan bersaing dengan produk-produk luar negeri. Jika tidak ada keterpihakan dan kebiajakan pemerintah untuk mendorong laju pertumbuhkan ekonomi berbasis local, tentu lambat hatun Indoensia akan terperangkap pada wilayah kecanduan dan ketergantungan terhadap pasokan barang-barang impor.

Terdapat beberapa penjelasan mengapa Indonesia masih belum bisa menciptakan perekonomian dengan tingkat kesejahteraan yang lebih baik. Dalam konteks dunia Internasional, Indonesia tidak bisa dikatakan sebagai failed-state, tidak juga sebagai negara yang belenggu hutang yang mematikan, namun harus diakui dan diwaspadai bahwa Indonesia sebenarnya dekat dengan situasi itu. Di tengah terpuruknya perekonomian dunia yang terus merosot dan melahirkan kemiskinan global, semakin 


\section{4 | Didi Suardi, MAKNA KESEJAHTERAAN DALAM SUDUT PANDANG EKONOMI ISLAM}

menunjukkan bahwa sistem perekonomian yang selama ini dianut tidak mampu memberikan solusi kesejahteraan dan keadilan. Dalam kenyatannya salah satu akar masalah kemiskinan di berbagai negara akibat terjerat oleh utang yang tinggi. Pada saat yang bersamaan, perkembangan sistem ekonomi syariah justru semakin kokoh dan semakin teruji dalam menghadapi krisis ekonomi global.

Penjelasan ini, seakan memberi petunjuk bahwa sistem ekonomi syariah dinilai mempunyai peran penting dalam program pengentasan kemiskinan, karena prinsip yang dibangun oleh sistem ekonomi syariah ini lebih berorientasi pada kesejahteraan, kemanusiaan, persaudaraan, keadilan, kesucian, kehormatan, kedamaian, ketenangan, keruhaniaan dan keharmonisan yang dirasakan secara bersama, bukan hanya pengumpulan harta sebanyak-banyak sebagaimana yang dianut pada prinsip ekonomi konvensional.

Dalam sistem ekonomi syariah mengenal istilah bagi hasil, yang mana konsep ini memungkinkan beban kerugian dan keuntungan menjadi milik bersama dan ditanggung bersama antara pemilik modal dan pengelola (Maskuro, 2017). Penanggungan secara bersama ini berdampak positif bagi stabilitas perekonomian. Sistem ekonomi berbasis syariah juga memberlakukan adanya pelarangan terhadap praktek riba dan mendorong pada kegiatan sektor riil. Pelarangan riba dalam sistem ekonomi syariah ini pun terbukti mampu mengendalikan inflasi dan menjaga stabilitas perekonomian yang berdampak pada pertumbuhan ekonomi secara merata dan berkesinambungan.

Islam mengatur sedemikian rupa akan masalah ekonomi umatnya, khususnya dalam hal kemiskinan. Banyak faktor yang menjadi penyebab kemiskinan, di antaranya karena ketidakpedulian orang-orang kaya yang mana menyebabkan orang-orang miskin semakin terjerat pada lingkaran kemiskinannya. Merespon tentang kondisi tersebut, Islam memberlakukan kewajiban kepada umatnya untuk membayar zakat sesuai ketentuan yang berlaku, dan anjuran berinfak dan bershadaqah sesuai kemampuannya.

Dalam ajaran Islam terdapat dua prinsip utama dalam kegiatan ekonomi yakni, Pertama: Islam melarang satu pihak mengeksploitasi pihak lain dengan alasan apa pun, Kedua: Islam melarang satu pihak membedakan, membatasi, dan memisahkan dengan pihak lainnya. Islam memandang bahwa umat manusia bagaikan satu keluarga, oleh 
sebab itu, setiap manusia memiliki hak, kewajiban dan derajat yang sama dalam lingkup sosial ekonomi, yang membedakan hanyalah tingkat keimanan dan ketwaaanya kepada Allah SWT. Begitu pun dalam pandangan hukum, setiap masyarakat ekonomi memiliki hak dan perlakuan yang sama dalam setiap kegiatan ekonomi, selama hak itu tidak bertentangan dengan norma-norma hukum yang ada.

Terciptanya kesejahteraan ekonomi rakyat merupakan tujuan utama berdirinya negara Republik Indonesia. Kesejahteraan dalam sistem ekonomi kapitalis hanya mengedepankan kebutuhan materi yang bersifat lahiriah, Konsep kesejahteraan menurut Islam lebih dari itu. Tulisan ini berangkat dari fenomena kegagalan sistem ekonomi kapitalis, dan memberikan alternatif sistem ekonomi Islam sebagai pemecahan masalah dari ketimpangan dan ketidakmerataan distribusi kekayaan yang menyebabkan radius kemiskinan semakin meningkat dan meluas.

\section{Pembahasan}

Ilmu ekonomi merupakan suatu cara manusia untuk mencapai kesejahteraan. Kesejahteraan yang dimaksud yakni segala sesuatu yang memiliki nilai dan harga. Terdapat tiga sistem ekonomi yang kini cukup dominan di dunia saat ini, yaitu kapitalisme, sosialisme dan Islam (Chapra, 1999) yang banyak digunakan di beberapa negara:

\section{Sistem Ekonomi Kapitalisme}

Paham kapitalisme berasal dari Inggris abad ke-18, kemudian menyebar ke Eropa Barat dan Amerika Utara. Sebagai akibat dari perlawanan terhadap ajaran gereja, tumbuh aliran pemikiran liberalisme di negara-negara Eropa Barat. Aliran ini kemudian merambah ke segala bidang termasuk bidang ekonomi. Dasar filosofis pemikiran ekonomi kapitalis bersumber dari tulisan Adam Smith dalam bukunya, An Inquiry into the Nature and Causes of the Wealth of Nations yang ditulis sekitar tahun 1776. Isi dari buku tersebut sarat dengan pemikiran-pemikiran tingkah laku ekonomi masyarakat.

Dari dasar filosofi tersebut kemudian menjadi sistem ekonomi dan pada akhirnya mengakar menjadi ideologi yang mencerminkan suatu gaya hidup (way of life). 


\section{6 | Didi Suardi, MAKNA KESEJAHTERAAN DALAM SUDUT PANDANG EKONOMI ISLAM}

Smith berpendapat bahwa motif manusia melakukan kegiatan ekonomi adalah atas dasar dorongan kepentingan pribadi, bertindak sebagai tenaga pendorong yang membimbing manusia mengerjakan apa saja asal masyarakat sedia membayar. Motif dan prinsip sistem kapitalis adalah perolehan, persaingan dan rasionalitas. Sedangkan tujuan kegiatan ekonominya adalah perolehan menurut ukuran uang (Manan, 1992).

\section{Sistem Ekonomi Sosialisme}

Sosialisme sebagaimana dirumuskan dalam Encyclopedia Britannica adalah suatu kebijakan atau teori yang bertujuan untuk memperoleh suatu distribusi yang lebih baik dengan tindakan otoritas demokrasi pusat. Prinsip-prinsip penting dalam sosialisme yang disosialisasikan kepada masyarakat, yaitu: Pertama, penghapusan milik pribadi atas alat-alat produksi. Hal ini akan digantikan menjadi milik pemerintah serta pengawasan atas industri dan pelayanan utama. Kedua; luasnya industri dan produksi mejadi kebutuhan sosial dan bukan kepada motif laba. Ketiga; pelayanan dan motif laba digantikan oleh motif pelayanan sosial.

Sosialisme muncul sebagai gerakan perlawanan ekonomi terhadap ketidakadilan yang timbul dari sistem kapitalisme. John Stuart Mill menyatakan gerakan sosialisme ditujukan untuk menolong orang-orang yang tidak beruntung dan tertindas (Hanifullah, 2012).

\section{Sistem Ekonomi Islam}

Muhammad Abdul Mannan mendefinisikan ekonomi Islam sebagai ilmu pengetahuan sosial yang mempelajari masalah-masalah ekonomi rakyat yang diilhami oleh nilai-nilai Islam. Ekonomi Islam merupakan sebuah konsep ekonomi yang dijalankan berdasarkan nilai-nilai dan prinsip-prinsip ajaran Islam yang bersumber pada al-Qur'an dan al-Sunnah, yang berorientasi pada pencapaian ridla Allah. Dalam hal ini, pencapaian ridha Allah adalah sebagai titik berangkat dari lahirnya ekonomi Islam.

Sistem ekonomi Islam yang dibangun berdasarkan nilai-nilai ajaran Islam yang tidak hanya berorientasi pada pencapaian profit semata, melainkan berorientasi pada nilai-nilai kemaslahatan bersama. Perbedaan mendasar antara ekonomi kapitalis dan 
ekonomi Islam, Dimana ekonomi konvensional berpijak pada dasar materialisme dan sekulerisme yang didasarkan hanya pada rasionalitas pemikiran manusia. Sedangkan ekonomi Islam pijakan dasarnya adalah al-Quran, as-Sunnah dan hasil ijtihad para intelektual muslim.

\section{Makna Kesejahteraan dalam Ekonomi Islam}

Ekonomi Islam kini telah menjadi pembahasan tersendiri pada masa modern sekarang ini. Kajian-kajian telah banyak dilakukan oleh para ulama mengingat pada masa awal pertumbuhan Islam, ekonomi Islam belum muncul sebagai sebuah disiplin keilmuan. Meskipun demikian, pondasi atau landasan dasarnya telah terealisasi di dalam sejarah Islam, sehingga hal inilah yang merupakan warisan yang terus menjadi sumber bagi berkembangnya nilai-nilai ekonomi Islam. Para ulama berperan besar di dalam memberikan penjelasan kepada para pelaku ekonomi dalam menjalankan kegiatan muamalahnya.

Kesejahteraan menurut al-Ghazali adalah tercapainya kemaslahatan. Kemaslahatan sendiri merupakan terpeliharanya tujuan syara' (Maqasid al-Shari'ah). Manusia tidak dapat merasakan kebahagiaan dan kedamaian batin, melainkan setelah tercapainya kesejahteraan yang sebenarnya dari seluruh umat manusia di dunia melalui pemenuhan kebutuhan-kebutuhan ruhani dan materi. Untuk mencapai tujuan syara agar dapat terealisasinya kemaslahatan, beliau menjabarkan tentang sumber kesejahteraan, yakni: terpeliharanya agama, jiwa, akal, keturunan dan harta (Rohman, 2010).

Konsep kesejahteraan tersebut dalam pandangan ekonomi Islam masih mencakup hanya dimensi materi. Ekonomi Islam menghendaki kesejahteraan itu juga mencakup keseluruhan unsur materi dan non materi (psikis). Hal ini disebabkan kepuasan manusia itu terletak pada unsur-unsur non materi. Kesejahteraan dalam fungsi matematisnya dapat dilihat dibawah ini (Aedy, 2011).

$$
\mathbf{I W}=\mathrm{MQ}+\mathrm{SQ}
$$

\section{Keterangan:}

IW = Islamic Welfare (Kesejahteraan yang Islami) 


\section{8 | Didi Suardi, MAKNA KESEJAHTERAAN DALAM SUDUT PANDANG EKONOMI ISLAM}

MQ = Material Quetient $($ Kecerdasan Material

SQ = Spiritual Quetient (Kecerdasan Spiritual)

Dalam fungsi diatas dapat diketahui bahwa kesejahteraan yang optimal dapat tercapai apabila kecerdasan material dikontrol oleh kecerdasan spiritual mulai dari cara memperolehnya sampai kepada membelanjakan. Dalam prakteknya, mereka yang memiliki kecerdasan spiritual dapat menjadi tenteram, aman, dan sejahtera meskipun mereka tidak memiliki kecerdasan material. Sedangkan manusia yang hanya memiliki kecerdasan material tidak akan pernah mendapatkan kebahagiaan meskipun dengan harta yang melimpah.

Kecerdasan Islami merupakan bagian fungsi dari kecerdasan material dan kecerdasan spiritual. Kecerdasan Islami dapat dicapai apabila hal-hal sebagai berikut dilakukan, yakni: benda yang dimiliki diperoleh dengan cara halal dan baik, bertujuan untuk ibadah, kualitas lebih dipentingkan daripada kuantitas, dan penggunaannya sesuai syariah (Almizan, 2016). Hal ini pun telah banyak dibahsas dalam al-Quran dan juga telah diaplikasikan dalam kehidupan Nabi Muhammad SAW.

\section{Kesejahteraan Menurut al-Qur'an}

Kesejahteraan merupakan tujuan dari ajaran Islam dalam bidang ekonomi. Kesejahteraan merupakan bagian dari rahmatan lil alamin yang diajarkan oleh Agama Islam ini. Namun kesejahteraan yang dimaksudkan dalam Al-Qur'an bukanlah tanpa syarat untuk mendapatkannya. Kesejahteraan akan diberikan oleh Allah SWT jika manusia melaksanakan apa yang diperintahkannya dan menjauhi apa yang dilarangnya (Syamsuddien, 1994).

Banyak ayat Al-Qur'an yang memberikan penjelasan tentang kesejahteraan ada yang secara langsung (tersurat) dan ada yang secara tidak langsung (tersirat) berkaitan dengan permasalahan ekonomi. Namun demikian, penjelasan dengan menggunakan dua cara ini menjadi satu pandangan tentang kesejahteraan. Allah SWT. berfirman dalam surah Al-Nahl ayat 97 yang berbunyi:

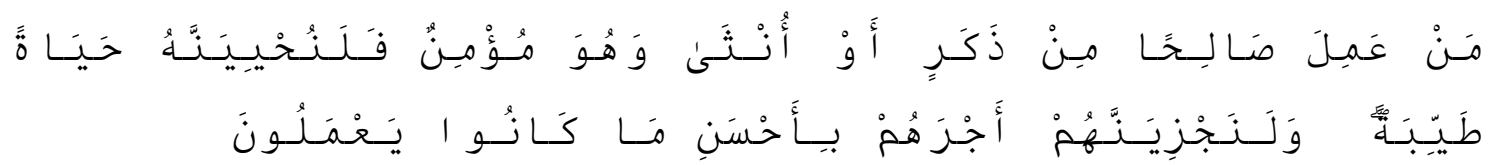


Artinya: "Barangsiapa yang mengerjakan amal saleh, baik laki-laki maupun perempuan dalam keadaan beriman, maka sesungguhnya akan Kami berikan kepadanya kehidupan yang baik dan sesungguhnya akan Kami beri balasan kepada mereka dengan pahala yang lebih baik dari apa yang telah mereka kerjakan”. (QS. alNahl: 97)

\section{Kesejahteraan pada Masa Rasulullah SAW.}

Ajaran Islam telah menjelaskan bahwa sesungguhnya tujuan dasar Islam adalah terwujudnya kesejahteraan baik di dunia maupun akhirat. Dalam prakteknya, Rasulullah SAW. Membangun suatu perekonomia yang dulunya dari titik nol menjadi suatu perekonomian raksasa yang mampu menembus keluar dari jazirah Arab. Pemerintahan yang dibangun Rasulullah SAW di Madinah mampu menciptakan suatu aktivitas perekonomian yang membawa kemakmuran dan keluasan pengaruh pada masa itu (Sholahuddin, 2009).

Kegiatan ekonomi telah menjadi sarana pencapaian kesejahteraan atau kemakmuran. Nabi Muhammad SAW memperkenalkan sistem ekonomi Islam. Hal ini berawal dari kerja sama antara kaum Muhajirin dan Anshar. Sistem ekonomi Islam yang diperkenalkan, antara lain, syirkah, qirad, dan khiyar dalam perdagangan. Selain itu, juga diperkenalkan sistem musaqah, mukhabarah, dan muzara'ah dalam bidang pertanian dan perkebunan. Para sahabat juga melakukan perdagangan dengan penuh kejujuran. Mereka tidak mengurangi timbangan di dalam berdagang.

Semenjak hijrah ke Madinah, kehidupan telah banyak berubah. Para sahabat Nabi Muhammad SAW dari kaum Muhajirin bahu membahu dengan penduduk lokal Madinah dari kaum Anshar dalam membangun kegiatan ekonomi. Berbagai bidang digeluti oleh beliau dan para sahabatnya baik itu pertanian, perkebunan, perdagangan dan peternakan. Pasar-pasar dibangun di Madinah. Kebunkebun kurma menghasilkan panenan yang melimpah. Peternakan kambing menghasilkan susu yang siap dipasarkan maupun hanya sekedar untuk diminum. Dalam sejarah, dikenal tokoh Islam yang terkenal dengan kekayaannya dan kepiawaiannya dalam berdagang dan berbagai bidang lainnya (Haekal, 1989). 


\section{0 | Didi Suardi, MAKNA KESEJAHTERAAN DALAM SUDUt PANDANG EKONOMI ISLAM}

Mereka adalah Abdurahman bin Awf, Abu Bakr, 'Umar bin Khattab, dan sebagainya. Mereka sadar akan dapat hidup di Madinah hanya dengan usaha mereka sendiri. Masyarakat Madinah terus berupaya meningkatkan aktivitas ekonomi dengan etos kerja yang tinggi. Ibadah dan kerja adalah dua jenis aktivitas ukhrawi dan duniawi yang menghiasi hari-hari mereka silih berganti. Pada awal tahun kedua Hijrah, Allah SWT sudah mewajibkan kaum muslimin membayar zakat. Tentu saja, zakat yang diwajibkan hanya bagi mereka yang telah berkecukupan.

Kesejahteraan ekonomi syariah bertujuan mencapai kesejahteraan manusia secara menyeluruh, yaitu kesejahteraan material, kesejahteraan spiritual dan moral. Konsep ekonomi kesejahteraan syariah bukan saja berdasarkan manifestasi nilai ekonomi, tetapi juga nilai spiritual dan moral (Anto, 2003). Konsepsi kesejahteraan dan kebahagiaan (falah) mengacu pada tujuan syariat Islam dengan terjaganya 5 prinsip dalam maqashid syari'ah, yakni terjanganya agama (ad-ddin), terjanganya jiwa (an$n a f s)$, terjanganya akal (al-aql), terjanganya keturunan (an-nasl) dan terjanganya harta (al-mal). Secara terperinci, tujuan ekonomi Islam dapat dijelaskan sebagai berikut:

a. Kesejahteraan ekonomi mencakup kesejahteraan individu, masyarakat dan negara.

b. Tercukupinya kebutuhan dasar manusia, meliputi makan, minum, pakaian, tempat tinggal, kesehatan, pendidikan, keamanan dan sistem negara yang menjamin terlaksananya kecukupan kebutuhan dasar secara adil (Sumito, 2010).

c. Penggunaan berdaya secara optimal, efisien, efektif, hemat dan tidak mubazir.

d. Distribusi harta, kekayaan, pendapatan dan hasil pembangunan secara adil dan merata.

e. Menjamin kebebasan individu.

f. Kesamaan hak dan peluang.

g. Kerjasamaan dan keadilan (Sumito, 2010).

\section{Simpulan}

Makna Kesejahteraan dalam ekonomi syariah bertujuan mencapai kesejahteraan manusia secara menyeluruh, yaitu kesejahteraan material, kesejahteraan spiritual dan moral. Konsep kesejahteraan ekonomi syariah bukan saja berdasarkan manifestasi nilai 
ekonomi, tetapi juga nilai spiritual dan moral. Konsepsi kesejahteraan dan kebahagiaan (falah) mengacu pada tujuan syariat Islam dengan terjaganya 5 prinsip dalam maqashid syari'ah, yakni terjanganya agama (ad-ddin), terjanganya jiwa (an-nafs), terjanganya akal (al-aql), terjanganya keturunan (an-nasl) dan terjanganya harta (al-mal). Secara terperinci, tujuan ekonomi Islam dapat dijelaskan sebagai berikut:

1. Kesejahteraan ekonomi mencakup kesejahteraan individu, masyarakat dan negara.

2. Tercukupinya kebutuhan dasar manusia, meliputi makan, minum, pakaian, tempat tinggal, kesehatan, pendidikan, keamanan dan sistem negara yang menjamin terlaksananya kecukupan kebutuhan dasar secara adil.

3. Penggunaan berdaya secara optimal, efisien, efektif, hemat dan tidak mubazir.

4. Distribusi harta, kekayaan, pendapatan dan hasil pembangunan secara adil dan merata.

5. Menjamin kebebasan individu.

6. Kesamaan hak dan peluang.

7. Kerjasamaan dan keadilan. 


\section{DAFTAR PUSTAKA}

\section{Buku}

Aedy, Hasan. 2011. Teori dan Aplikasi Ekonomi Pembangunan Perspektif Islam Sebuah Studi Komparasi. Yogyakarta: Graha Ilmu.

Anshari, Endang Saiffudin. 1981. Ilmu Filsafat dan Agama. Surabaya: PT. Bina Ilmu.

Anto, M.B. Hendrie. 2003. Pengantar Ekonomika Mikro Islami, Cet.I. Yogyakarta: Ekonosia.

Arsyad, Lincoln. 1999. Ekonomi Mikro. Jakarta: Gemapress.

As-Suyuthi, Imam Jalaluddin. al-Asybah Wan-Nadhoir. Surabaya: al-Haromain, Tth.

Basri, Ikhwan Abidin. 2005. Islam dan Pembangunan Ekonomi. Jakarta: Gema Insani Press.

Beckarman, International Comparition of Real Income, Development Centre of Thr Oecd dalam Sadono Sukirno.

Chapra, M. Umar. 2000. Islam dan Pembangunan Ekonomi. Jakarta: Gema Insani. 1999. Islam dan Tantangan Ekonomi, Terj. Nur Hadi Ihsan dan Rifqi Amar, Cet. I. Surabaya: Risalah Gusti. . 2001. Masa Depan Ilmu Ekonomi Sebuah Tinjauan Islam, Cet. I. Jakarta: Gema Insani Press. . 2001. The Future of Economics: An Islamic Perspective. Terj. Jakarta: Sebi.

Haekal, Muhammad Husain. 1989. Sejarah Hidup Muhammad. Jakarta: Litera Antar Nusa.

Jogiyanto. 2005. Analisis dan Desain Sistem Informasi. Yogyakarta: Andi.

Kahf, Monzer. 1995. Ekonomi Islam: Telaah Analitik Terhadap Fungsi Sistem Ekonomi Islam, Terj. Machnun Husein. Yogyakarta: Pustaka Pelajar.

Karim, Adiwarman. 2002. Ekonomi Islam: Suatu Kajian Ekonomi Makro, Cet. I. Jakarta: IIIT Indonesia.

Karim, Adiwarman. 2003. Ekonomi Mikro Islami, Cet. II. Jakarta: IIIT Indonesia.

Mannan, Muhammad Abdul. 1992. Ekonomi Islam: Teori dan Praktik, Terj. Potan Arif Harahap. Jakarta: PT. Intermasa.

1997. Teori dan Praktek Ekonomi Islam, Terj. Nastangin. Yogyakarta: PT. Dana Bhakti Wakaf.

Nasution, Mustafa. 2007. Pengenalan Ekslusif Ekonomi Islam. Jakarta: Kencana.

Rohman, Abdur. 2010. Ekonomi Al-Ghazali; Menelusuri Konsep Ekonomi Islam dalam Ihya' Ulum al-Din. Surabaya: Bina Ilmu. 
Salvatone, Dominick. 2009. Teori Mikroekonomi. Jakarta: Erlangga,.

Sholahuddin, Muhammad. 2009. World Revolution with Muhammad. Sidoarjo: Mashun.

Shomad, Abd. 2010. Hukum Islam. Jakarta: Kencana.

Suherman, Bonnie dan Marin Pinontoan. 2008. Designing Information System. Jakarta: Elex Media Komputindo.

Sumito, Warkum. 2010. Asas-asas Perbankan Islam \& Lembaga-lembaga Terkait. Cet Keempat. Jakarta: Raja Grafindo Persada.

Syamsuddien, Darsyaf Ibnu. 1994. Prototype Negeri Yyng Damai. Surabaya: Media Idaman Press.

Syarifuddin, Amir. 2011. Ushul Fiqh, Jilid 1. Jakarta: Kencana.

Wildan, Muhammad. "Sistem Ekonomi Islam Simbol Kesejahteraan Masyarakat". ElJizya; Islamic Economics Journal, Vol. 6, No. 1 Januari-Juni 2018.

\section{Jurnal}

Djumadi. “Konsep Pembangunan Ekonomi Perspektif Islam”. Jurnal Tahkim Vol. XII, No. 1, Juni 2016.

Hanifullah, "Membangun Sistem Ekonomi Umat Berbasis Syariah", Jurnal Epistemé, Vol. 7, No. 2, Desember 2012.

Maskuro, Nihayatul. "Gagasan Pemikiran Ekonomi Islam: Implementasi dan Usaha Pengembangannya", Li-Falah: Jurnal Studi Ekonomi dan Bisnis Islam Volume 2, Nomor 2, Desember 2017.

Nailufarh, Qurratul A’yun. "Kesejahteraan Ekonomi Rakyat; diantara Harapan dan Realitas", Balance Economics, Bussiness, Management and Accounting Journal Th. VII No. 12 Januari 2010.

Purbaya, A. Ghofar. "Strategi Peningkatan Kesejahteraan Ekonomi Masyarakat: Kasus Pengusaha Krupuk dan Camilan Hasil Laut di Pantai Kenjeran Lama Surabaya". Oeconomicus; Journal Of Economics Volume 1, No. 1, Des 2016.

Maddison, Agus. Monitoring The World Economy, Oecd Paris dalam Sadono Sukirno.

Hamid, M. Arfin. “Ekonomi Klasik ke Sistem Syariah”, http://www.-fajar. co.id 
334 | Didi Suardi, MAKNA KESEJAHTERAAN DALAM SUDUT PANDANG EKONOMI ISLAM 